\title{
KEEFEKTIFAN Lecanicillium lecanii MENGENDALIKAN Crocidolomia pavonana PADA SKALA LABORATORIUM
}

\author{
Helmi Natul Widan $^{1}$ Efrin Firmansyah $^{2 *}$ Siti Nurhidayah $^{3}$ \\ ${ }^{1,3}$ Agroteknologi Pertanian, Universitas Perjuangan Tasikmalaya \\ ${ }^{2}$ Agroteknologi, UIN Sunan Gunung Djati Bandung \\ *efrin@uinsgd.ac.id
}

\begin{abstract}
Abstrak
Cendawan L. lecanii merupakan agens hayati yang potensial untuk mengendalikan hama pada tanaman. Percobaan ini dilaksanakan di Laboratorium Satuan Pelayanan Balai Perlindungan Tanaman Pangan dan Hortikultura Wilayah V Tasikmalaya Penelitian ini menggunakan Rancangan Acak Lengkap (RAL) faktor tunggal dengan 6 perlakuan dan 5 ulangan, yaitu Konsentrasi L. lecanii : P0 (Kontrol), P1 (5 g.L $\left.\mathrm{L}^{-1}\right), \mathrm{P} 2$ (10 g.L L $^{-1}$, P3 (15 g.L $\left.{ }^{-1}\right)$, P4 (20 g.L $\left.{ }^{-1}\right)$, P5 (25 g.L $\left.{ }^{-1}\right)$. Variabel yang yang diamati yaitu mortalitas, konsumsi pakan larva c. pavonana, perilaku larva yang terinfeksi, lama waktu kematian larva. Perlakuan yang menunjukan hasil optimal ada pada perlakuan P5 (Konsentrasi L. lecanii 25 g. $\mathrm{L}^{-1}$ ) dengan nilai mortalitas $82 \%$, konsumsi pakan $1.23 \mathrm{~g}$, lama waktu kematian 1.8 HSA dan perilaku larva yang terinfeksi yaitu $C$. pavonana mengalami perubahan warna, yang awalnya berwarna kuning berubah menjadi warna hitam. Tubuh larva menjadi keras, karena semua jaringan dan cairan dalam tubuh larva habis oleh cendawan L. lecanii, lalu secara perlahan diselimuti oleh miselium.
\end{abstract}

Kata kunci : Agens hayati, L. lecanii, C. pavonana, Kubis, Konsentrasi

\section{Abstract}

L. lecanii is one of the biological agents which have the potential to be used in controlling several pests and plant diseases. This experiment was carried out at the Laboratory of the Service Unit of BPTPH, Region V Tasikmalaya. This study used a single factor completely randomized design (CRD) with 6 treatments and 5 replications, namely the concentration of L. lecanii: $P 0$ (Control), P1 (5 $\left.\mathrm{gL}^{-1}\right)$, P2 (10 $\left.\mathrm{gL}^{-1}\right)$, P3 (15 $\left.\mathrm{gL}^{-1}\right)$, P4 $\left(20 \mathrm{gL}^{-1}\right)$, P5 $\left(25 \mathrm{gL}^{-1}\right)$. The variables observed were mortality, larvae feed consumption, behavior of infected larvae, long time of death of larvae. The treatment that showed optimal results was in the P5 treatment ( $L$. lecanii concentration of $25 \mathrm{gL}^{-1}$ ) with a mortality value of $82 \%$, feed consumption of $1.23 \mathrm{~g}$. and the duration of death was 1.8 DAT and the behavior of infected larvae, namely $C$. pavonana, experienced changes color, which initially turns yellow into black. The larva's body becomes hard, because all the tissue and fluid in the larva's body is depleted by the L. lecanii, then it is slowly covered by mycelium.

Keyword: Biological agent, C. pavonana, Cabbage, Consentration, L. lecanii

\section{Pendahuluan}

Tanaman kubis merupakan salah satu komoditas sayuran yang popular ditanam oleh petani Indonesia. Tanaman kubis cocok tumbuh di dataran rendah dan dataran medium (Sastrosiswojo et al., 2005). Budidaya tanaman kubis di Indonesia pada umumnya dilakukan dalam rangka untuk memenuhi keperluan dalam negeri dan ekspor. Salah satu factor yang menentukan keberhasilan budidaya kubis adalah adanya serangan hama pada tanaman,, termasuk $C$. pavonana Pada umumnya petani melakukan pengendalian hama secara kimia dengan mengaplikasikan pestisida. Namun demikian penggunaan pestisida yang terus menerus dapat menimbulkan dampak negative pada lingkungan.

Hama $C$. pavonana menyerang tanaman kubis dengan cara memakan daun yang masih muda sampai habis. Kemudian hama ini menyerang bagian titik tumbuh tanaman inangnya. Serangan tersebut menyebabkan bagian tanaman mati karena bagian dalamnya menjadi busuk. Menurut kristanto et al., (2013) serangan $C$. pavonana dapat mengakibatkan penurunan produksi kubis sebesar 79,81\%.

Cendawan $L$. lecanii adalah salah satu agens hayati yang potensial sebagai pengendali beberapa hama dan penyakit tanaman. Cendawan $L$. lecanii memiliki karaktersitik yaitu kisaran inangnya luas dan bersifat kosmopolit. Karakter tersebut adalah alasan cendawan ini mudah ditemukan di daerah tropis maupun sub tropis. Pada penelitian terpisan, L. lecanii dilaporkan 
menghasilkan metabolit sekunder bersifat toksik, yaitu bassionolidae dan asam dipicolinic yang bersifat insektisidal.

Beberapa ordo serangga yang diketahui dapat terinfeksi atau terkendalikan oleh cendawan L. lecanii adalah ordo Orthoptera, Hemiptera Lepidoptera, Thysanoptera dan Coleoptera. Cendawan ini pertama kali ditemukan menginfeksi kutu sisik scale insect (Homoptera: Diaspididae) yang merupakan hama tanaman kopi di pulau Jawa (Khaerati dan Gusti, 2015). Hasil penelitian Khoiroh et al., (2014) menyatakan patogenitas cendawan $L$. lecanii efektif mengendalikan wereng coklat dengan konsentrasi $10^{10}$ konidia $\mathrm{ml}^{-1}$ sebagai nilai kerapatan konidia paling efektif, yang menyebabkan mortalitas mencapai $78,33 \%$ dan waktu kematian hingga 5,81 hari setelah aplikasi (HSA)

Penggunaan cendawan $L$. lecanii masih sangat jarang digunakan oleh petani untuk menekan perkembangan hama pada tanaman kubis, dengan menggunakan L. lecanii pada pengendalian hama tanaman kerapatan $10^{8}$ mampu mengendalikan Spodoptera exigua (Larva instar ke-3) dengan mortalitas 70\% (Wahyuni et al., 2013). Penggunaan cendawan $L$. lecanii dirasa mampu menekan perkembangan hama $C$. pavonana pada tanaman kubis, dengan menggunakan kerapatan cendawan $10^{8}$ pada larva instar 3, untuk itu diperlukan penelitian lebih lanjut dengan mencari konsentrasi yang tepat untuk ditemukannya komposisi pengendalian yang mampu menekan pertumbuhan hama agar menjadi inovasi teknologi yang mampu dikembangkan oleh petani.

Upaya tersebut dapat dimulai dari aktivitas penelitian di laboratorium sehingga tujuan dari penelitian ini adalah untuk mendeskripsikan pengaruh pemberian $L$. lecanii terhadap larva $C$. Pavonana dan menentukan konsentrasi yang optimal pemberian $L$. lecanii sebagai agens hayati untuk mengendalikan $C$. pavonana pada skala laboratorium.

\section{Bahan dan Metode}

\section{Tempat dan Waktu}

Percobaan dilaksanakan di Laboratorium Satuan Pelayanan Balai Perlindungan Tanaman Pangan dan Hortikultura (Satpel BPTPH) Wilayah V Tasikmalaya, Kecamatan Cihideung Kota Tasikmalaya, ketinggian tempat $\pm 386 \mathrm{mdpl}, 07^{\circ} 19,854 \mathrm{LS}, 108^{\circ} 12.193 \mathrm{LU}$ dan suhu rata-rata $26-29{ }^{\circ} \mathrm{C}$ Pelaksanaan percobaan dimulai pada bulan April - Desember 2020.

\section{Sumber isolat L. Lecanii}

Sumber L. Lecanii berasal dari Balai Besar Peramalan Organisme Pengganggu Tumbuhan (BBPOPT) dan di perbanyak di Laboratorium Satuan
Pelayanan Balai Perlindungan Tanaman Pangan dan Hortikultura (Satpel BPTPH) Wilayah V Tasikmalaya pada media jagung dengan kerapatan L. Lecanii $10^{8}$.

\section{Sumber inokulum C. Pavonana}

Sumber C. Pavonana berasal dari Balai Penelitian Tanaman Sayuran (BALITSA) dan di perbanyak di Laboratorium Satuan Pelayanan Balai Perlindungan Tanaman Pangan dan Hortikultura (Satpel BPTPH) Wilayah V Tasikmalaya.

\section{Rancangan percobaan}

Penelitian ini menggunakan rancangan acak lengkap (RAL) faktor tunggal dengan 6 perlakuan dan 5 ulangan, yaitu konsentrasi L. lecanii: P0 (Kontrol), P1 (5 g. . $\left.{ }^{-1}\right)$, P2 (10 g. $\left.L^{-1}\right)$, P3 (15 g.L $\left.L^{-1}\right)$, P4 (20 g.L $\left.L^{-1}\right)$ dan P5 (25 g.L $\left.{ }^{-1}\right)$.

\section{Teknik aplikasi L. Lecanii}

L. Lecanii yang diperbanyak pada media jagung dengan kerapatan $10^{8}$ di tumbuk halus dan kemudian di buat suspensinya sesuai dengan konsentrasi yang sudah ditentukan. Teknik aplikasi L. Lecanii yaitu dengan cara di semprotkan pada kotak yang berisi ulat $C$. Pavonana dan setiap kotak berisi 10 ulat instar 3 .

\section{Analisis data}

Analisis data yaitu dengan cara mengamati pertumbuhan dan perkembangan L. Lecanii yang di aplikasikan pada ulat $C$. Pavonana dan menimbang setiap pakan yang di berikan dan sisa pakan yang diberikan pada ulat C. Pavonana.

\section{Hasil dan Pembahasan}

\section{Mortalitas}

Hasil pengujian menunjukkan perlakuan cendawan L. Lecanii untuk mengendalikan $C$. Pavonana mendapatkan hasil persentase mortalitas sebagai berikut yang dituangkan dalam Tabel 1 .

Data pengujian menunjukan pemberian L. lecanii dengan perlakuan P5 Konsentrasi 25 g. $\mathrm{L}^{-1}$ tidak berbeda nyata dengan perlakuan P2 (10 g. $\left.\mathrm{L}^{-1}\right)$, P3 (15 g. $\left.\mathrm{L}^{-1}\right)$ dan P4 (20 g. $\left.\mathrm{L}^{-1}\right)$. Pemberian L. lecanii dengan perlakuan P1 Konsentrasi 5 g. $\mathrm{L}^{-1}$ berbeda nyata terhadap setiap perlakuan. Dari hasil rata-rata mortalitas perlakuan P5 dengan konsentrasi L. lecanii 25 g. $\mathrm{L}^{-1}$ menunjukan tingkat mortalitas tertinggi mencapai $82 \%$, 
Tabel 1. Pengaruh aplikasi L. lecanii terhadap mortalitas larva C. pavonana

\begin{tabular}{ll}
\hline \multicolumn{1}{c}{ Perlakuan } & $\begin{array}{l}\text { Rata-rata } \\
\text { mortalitas (\%) }\end{array}$ \\
\hline P0-: Kontrol & $0^{\mathrm{c}}$ \\
P1-: L. lecanii 5 g.L ${ }^{-1}$ & $36^{\mathrm{b}}$ \\
P2-: L. lecanii 10 g.L ${ }^{-1}$ & $66^{\mathrm{a}}$ \\
P3-: L. lecanii 15 g.L ${ }^{-1}$ & $66^{\mathrm{a}}$ \\
P4-: L. lecanii 20 g.L $\mathrm{L}^{-1}$ & $78^{\mathrm{a}}$ \\
P5-: L. lecanii 25 g.L $\mathrm{L}^{-1}$ & $82^{\mathrm{a}}$
\end{tabular}

Keterangan : Angka rata-rata yang diikuti huruf yang sama pada setiap kolom, tidak berbeda nyata berdasarkan uji jarak Berganda Duncan pada taraf nyata $5 \%$.

\section{Konsumsi pakan larva C. Pavonana}

Berdasarkan hasil penelitian L. lecanii sebagai agens hayati untuk mengendalikan $C$. pavonana pada tanaman kubis menghasilkan data Pengaruh aplikasi $L$. lecanii terhadap aktivitas makan larva sebagai berikut:

Tabel 2. Pengaruh aplikasi L. lecanii terhadap aktivitas makan larva

\begin{tabular}{ll}
\hline Perlakuan & Penghambat makan $(\mathrm{g})$ \\
\hline P0 : Kontrol & $1.85^{\mathrm{d}}$ \\
P1 : L. lecanii 5 g.L. & $1.68^{\mathrm{cd}}$ \\
P2 : L. lecanii 10 g.L $\mathrm{L}^{-1}$ & $1.66^{\mathrm{cd}}$ \\
P3 : L. lecanii 15 g.L & $1.51^{\mathrm{bc}}$ \\
P4 : L. lecanii 20 g.L & $1.39^{\mathrm{ab}}$ \\
P5 : L. lecanii 25 g.L & $1.23^{\mathrm{a}}$
\end{tabular}

Keterangan : Angka rata-rata yang diikuti huruf yang sama pada setiap kolom, tidak berbeda nyata berdasarkan uji jarak Berganda Duncan pada taraf nyata $5 \%$.

Tabel penghambat makan menunjukan bahwa Konsumsi pakan terendah ada pada perlakuan P5 dengan konsentrasi L. lecanii 25 g.L L $^{-1}$, yang berarti memiliki pengaruh penghambat makan tertinggi. Hasil pengamatan pada konsumsi pakan dihasilkan perlakuan P5 konsentrasi $L$. lecanii 25 g. $\mathrm{L}^{-1}$ tidak berbeda nyata dengan perlakuan P4 konsentrasi L. lecanii 20 g. $\mathrm{L}^{-1}$. Akan tetapi, perlakuan P5 konsentrasi L. lecanii 25 g.L - $^{-1}$ dan perlakuan P4 konsentrasi L. lecanii 20 g.L $\mathrm{L}^{-1}$ berbeda nyata dengan setiap perlakuan yang ada. Perlakuan P3 konsentrasi L. lecanii 15 g. $\mathrm{L}^{-1}$ berbeda nyata dengan perlakuan P2 konsentrasi L. lecanii 10 g. $\mathrm{L}^{-1}$, dan perlakuan P1 konsentrasi L. lecanii 5 g. $\mathrm{L}^{-1}$, sedangkan perlakuan P2 konsentrasi L. lecanii 10 g. $\mathrm{L}^{-1}$ tidak berbeda nyata dengan perlakuan P1 konsentrasi $L$. lecanii 5 g.L ${ }^{-1}$. Angka yang ada pada Tabel 2 menunjukan semakin kecil angkanya maka terjadi penurunan aktivitas makan yang menjadikan adanya penghambatan makan pada setiap perlakuan. Penurunan aktivitas makan terjadi pada perlakuan P5 konsentrasi $L$. lecanii 25 g. $\mathrm{L}^{-1}$.

Terjadinya penurunan aktivitas makan pada $C$. pavonana diakibatkan karena adanya perubahan fisik yang terjadi pada larva $C$. pavonana. Setelah perlakuan larva cenderung melambat dikarenakan aktivitas cendawan $L$. lecanii yang mulai diserap oleh tubuh larva. Menurut Gindin et al., (2000) serangga yang terserang entomopatogen dapat mengalami penurunan aktifitas makan yang diakibatkan terganggunya system syaraf pada serangga.

\section{Perilaku larva yang terinfeksi}

Pengamatan ini bertujuan untuk mengetahui perilaku larva $C$. pavonana setelah diberikan perlakuan, dan untuk mengetahui tingkat evektifitas penggunaan Cendawan L. lecanii pada tubuh larva sampai tubuh dari C. pavonana diselimuti oleh miselium.
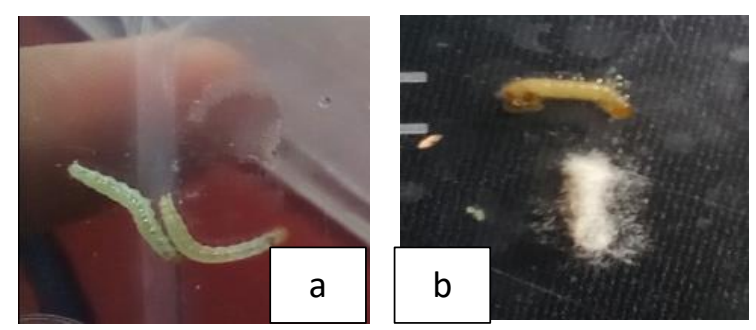

Gambar 1. Perubahan larva C. pavonana (a) 1 hari sesudah aplikasi dan (b) 8 hari sesudah aplikasi L. lecanii

Gejala yang ditimbulkan akibat larva yang terinfeksi $L$. lecanii yaitu setelah di semprot dengan cairan yang mengandung cendawan $L$. lecanii larva $C$. pavonana mengalami perubahan warna, yang awalnya berwarna kuning seperti pada Gambar 1a yang kemudian berubah menjadi warna hitam. Tubuh serangga menjadi keras, karena semua jaringan dan cairan dalam tubuh serangga habis oleh cendawan $L$. lecanii, lalu secara perlahan diselimuti oleh miselium seperti pada Gambar 1b.

Pada umumnya, entomopatogen masuk ke dalam tubuh inang melalui membran intersegmental kemudian menyebar ke seluruh bagian lapisan dinding tubuh larva. Di bantu oleh enzim proteinase, lipase, dan kitinase. Patogenitas yang di miliki setiap cendawan berbeda-beda karena toksin yang dimiliki juga berbeda menyebabkan gejalan kematian pada inang berbeda pula. L. lecanii menginfeksi inangnya dengan dua cara yaitu secara mekanik dan enzim hidrolitik untuk dapat 
menembus integumen serangga dan dinding sel cendawan (Shinde et al., 2010).

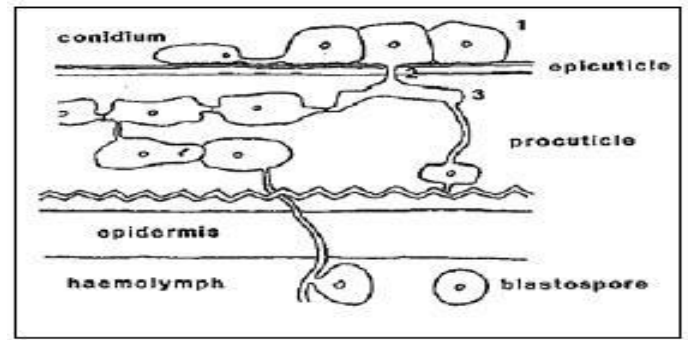

Gambar 2. Infeksi cendawan entomopatogen. (Sumber: Shinde et al., 2010)

Setelah cendawan berhasil penetrasi pada bagian kutikula, selanjutnya akan mengkolonisasi inang. Hifa dan konidia yang ada dalam tubuh serangga menyebar melalui aliran hemolimfa menuju organ dan jaringanjaringan di dalam tubuh serangga. Hifa selanjutnya berkembang dan memperbanyak diri dengan menyerap cairan tubuh serangga inangnya. Apabila hifa telah menemukan organ dan jaringan-jaringan sasarannya, pada tubuh serangga inang akan terbentuk kumpulan miselium di atas permukaan integumen yang mengakibatkan kematian inang/mumifikasi (Shinde et al., 2010). Pada kondisi lingkungan yang tepat, konidiofor membentuk konidia untuk siklus penyakit selanjutnya.

Tabel 3. Pengaruh aplikasi L. lecanii terhadap perilaku larva terinfeksi

\begin{tabular}{|c|c|}
\hline Perlakuan & Perilaku larva \\
\hline P0 : Kontrol & Normal \\
\hline $\mathrm{P} 1$ : L. lecanii 5 g. $\mathrm{L}^{-1}$ & Normal, Gerak lambat, kaku \\
\hline $\mathrm{P} 2$ : L. lecanii 10 g.L $\mathrm{L}^{-1}$ & $\begin{array}{l}\text { Gerak lambat, kaku, larva } \\
\text { menguning }\end{array}$ \\
\hline P3 : L. lecanii 15 g.L $\mathrm{L}^{-1}$ & $\begin{array}{l}\text { Gerak lambat, kaku, mati, dan } \\
\text { berubah menguning }\end{array}$ \\
\hline P4 : L. lecanii 20 g. $\mathrm{L}^{-1}$ & $\begin{array}{l}\text { Gerak lambat, kaku, } \\
\text { menguning, tertutup miselium } \\
\text { tipis }\end{array}$ \\
\hline P5 : L. lecanii 25 g.L $\mathrm{L}^{-1}$ & $\begin{array}{l}\text { Gerak lambat, kaku, } \\
\text { menguning, tertutup miselium } \\
\text { tipis }\end{array}$ \\
\hline
\end{tabular}

Tabel 3 menjelaskan adanya perubahan perilaku yang ditunjukan oleh larva setelah diberikan perlakuan cendawan L. Lecanii, perlakuan P1 menunjukan larva sampai kaku, perlakuan P2 menunjukan perilaku larva sampai berubah warna menguning, perlakuan P3 larva mati dan berubah warna menjadi menguning, dan perlakuan P4 dan P5 menunjukan perilaku larva berubah warna dan tertutupi miselium.

\section{Lama waktu kematian larva}

Pengamatan ini bertujuan untuk mengetahui seberapa cepat efektifitas cendawan $L$. lecanii sebagai agen hayati terhadap larva $C$. pavonana, hasil data olahan disajikan dalam Tabel 4.

Tabel 4. Pengaruh aplikasi L. lecanii terhadap waktu kematian C. pavovana

\begin{tabular}{|c|c|}
\hline Perlakuan & Rata-rata waktu kematian (HSA) \\
\hline $\mathrm{P} 1:$ L. lecanii 5 g.L $\mathrm{L}^{-1}$ & $4.0^{\mathrm{b}}$ \\
\hline $\mathrm{P} 2$ : L. lecanii 10 g. $\mathrm{L}^{-1}$ & $2.2^{\mathrm{ab}}$ \\
\hline $\mathrm{P} 3$ : L. lecanii 15 g.L $\mathrm{L}^{-1}$ & $2.2^{\mathrm{ab}}$ \\
\hline $\mathrm{P} 4$ : L. lecanii 20 g. $\mathrm{L}^{-1}$ & $2.2^{\mathrm{ab}}$ \\
\hline P5 : L. lecanii 25 g.L $\mathrm{L}^{-1}$ & $1.8^{\mathrm{ab}}$ \\
\hline
\end{tabular}

Keterangan : Angka rata-rata yang diikuti huruf yang sama pada setiap kolom, tidak berbeda nyata berdasarkan uji jarak Berganda Duncan pada taraf nyata $5 \%$

Pemberian konsentrasi $L$. lecanii pada larva $C$. pavonana menunjukan adanya mortalitas dengan waktu kematian berdasarkan hasil pengamatan yang tersaji dalam Tabel 4. Perlakuan P5 konsentrasi L. lecanii 25 g. $\mathrm{L}^{-1}$ tidak berbeda nyata dengan perlakuan P4 konsentrasi L. lecanii 20 g. $\mathrm{L}^{-1}$, perlakuan P3 konsentrasi L. lecanii 15 g. $\mathrm{L}^{-1}$ dan perlakuan $\mathrm{P} 2$ konsentrasi $L$. lecanii 10 g. $\mathrm{L}^{-1}$. Akan tetapi, perlakuan P1 konsentrasi L. lecanii 5 g. $\mathrm{L}^{-1}$ berbeda nyata dengan setiap perlakuan. Perlakuan P5 konsentrasi L. lecanii 25 g.L - $^{-1}$ menunjukan adanya efektifitas pemberian $L$. lecanii dengan waktu kematian tercepat yaitu 1,8 HSA. Menurut Suharsono dan Prayogo (2005) koloni Cendawan entomopatogen yang menyelimuti tubuh berwarna putih pucat, dua hari setelah inokulasi Cendawan sudah mampu memproduksi konidia, infeksi yang disebabkan oleh Cendawan entomopatogen pada tubuh serangga melibatkan aktivitas enzim dan toksin. Dengan demikian rata-rata hari yang diperlukan untuk cendawan menginokulasi tubuh inangnya hanya membutuhkan waktu 2 hari dengan suhu dan kelembapan yang mendukung.

\section{Kesimpulan}

Berdasarkan hasil penelitian, kesimpulan yang diperoleh adalah sebagai berikut:

1. Terdapat perbedaan nyata pada setiap perlakuan pemberian cendawan L. lecanii, gejala yang ditimbulkan oleh larva yang terinfeksi $L$. lecanii yaitu setelah beberapa hari setelah aplikasi larva mati, tubuh larva mengeras karena semua jaringan dan cairan dalam tubuh larva terinfeksi oleh cendawan $L$. 
lecanii.

2. Larva menjadi hitam dan kaku, kemudian secara perlahan larva diselimuti oleh miselium yang terjadi pada perlakuan $\mathrm{P} 4$ konsentrasi $L$. lecanii 20 g. $\mathrm{L}^{-1}$ dan P5 konsentrasi L. lecanii 25 g. $\mathrm{L}^{-1}$

\section{Ucapan Terimakasih}

Penulis mengucapkan terimaksih kepada kepala Satuan Pelayanan Balai Perlindungan Tanaman Panagan dan Hortikultura Wilayah V Tasikmalaya, yang telah memfasilitasi laboratorium untuk pelaksanaan penelitian ini.

\section{Daftar Pustaka}

Gindin, G., Geschtovt, N.U., Raccah, B., Barash, I. (2000). Pathogenicity of Verticillium lecanii to different development stages of the silverleaf whitefly Bemisia argentifolii. Phytopar, 28(3): 231-242.

Khaerati., Indriati, G. (2015). Lecanicillium lecanii (Ascomycota: Hypocreales) sebagai agens hayati pengendali hama dan penyakit tanaman. Balai Penelitian Tanaman Industri dan Penyegar. Sirnov, 3(2): 93-102.

Khoiroh, F., Isanwati., Faizah, U. (2014). Patogenitas cendawan entomopatogen (lecanicillium lecanii) sebagai bioinsektisida untuk pengendalian hama Wereng coklat secara in vitro. LenteraBio, 3(2): 115-121.

Kristanto, S.P., Sutjipto., Soekarto. (2013). Pengendalian hama pada tanaman kubis dengan sistem tanaman tumpangsari. Berkala Ilmiah Pertanian, 1(1): 7-9.

Prayogo, Y. (2011). Biopestisida ramah lingkungan dari Lecanicillium lecanii. Sinar Tani Edisi: 22 28 Juni 2011. Balai Penelitian Tanaman Kacang-kacangan dan Umbi-umbian. Malang. Indonesia

Shinde, S.V., Patel, K.G., Purohit, M.S., Pandya, J.R., Sabalpara, A.N. (2010). Lecanicillium lecanii (Zimm.) Zare and Games an important biocontrol agent for the management of insect pests - A riview. Agr. Review, 31(4): 235-252.

Sastrosiswojo, S., Uhan, T.S., Sutarya, R. (2005). Penerapan teknologi PHT Pada tanaman kubis. Bandung. Balai Penelitian Tanaman Sayuran. 75.

Sunarjono, H.H. (2011). Bertanam 30 jenis sayuran. Jakarta. Penebar Swadaya.

Suharsono., Prayogo, Y. (2005). Pengaruh lama pemaparan pada sinar matahari terhadap viabilitas Cendawan entomopatogen Verticillium lecanii. Jurnal Habitat, 16(2): 122-131.

Wahyuni, D.T., Isnawati., Suparno, G. (2013). Patogenisitas cendawan entomopatogen Lecanicillium lecanii (Zimmerman) Viegas terhadap larva instar III Spodoptera exigua (Lepidoptera: Noctuidae). LenteraBio, 2(2): 173-178. 